\title{
Stem Cell Factors in Plants: Chromatin Connections
}

\author{
N. KORNET AND B. SCHERES \\ Department of Molecular Cell Biology, Utrecht University, 3584 CH Utrecht, The Netherlands
}

\begin{abstract}
The progression of pluripotent stem cells to differentiated cell lineages requires major shifts in cell differentiation programs. In both mammals and higher plants, this process appears to be controlled by a dedicated set of transcription factors, many of which are kingdom specific. These divergent transcription factors appear to operate, however, together with a shared suite of factors that affect the chromatin state. It is of major importance to investigate whether such shared global control mechanisms indicate a common mechanistic basis for preservation of the stem cell state, initiation of differentiation programs, and coordination of cell state transitions.
\end{abstract}

\section{CELL STATE, TRANSCRIPTIONAL ACTIVITY, AND CHROMATIN}

In the nucleus, DNA is compacted by chromatin, but it still remains dynamic and accessible for transcription (for review, see Luger and Hansen 2005; Mellor 2005). The nucleosome core particle is the base of the chromatin structure and consists of $147 \mathrm{bp}$ of DNA wrapped around a histone octamer core (formed by two copies of histones $\mathrm{H} 2 \mathrm{~A}, \mathrm{H} 2 \mathrm{~B}, \mathrm{H} 3$, and $\mathrm{H} 4$ ).

The chromatin state can be influenced in four ways: (1) Methylation of the DNA can take place (Bernstein et al. 2007), (2) histone variants can be incorporated with properties different from those of the core histones (for review, see Kamakaka and Biggins 2005; Hake and Allis 2006; Loyola and Almouzni 2007), (3) sliding or replacement of nucleosomes can be facilitated by ATP-dependent chromatin remodelers (for review, see Cairns 2005; Kwon and Wagner 2007), and (4) both the nucleosomal core and the histone tails can be posttranslationally modified, including acetylation, methylation, phosphorylation, ubiquitination, and sumoylation (for review, see Peterson and Laniel 2004; Bannister and Kouzarides 2005; Margueron et al. 2005; Kouzarides 2007; Shahbazian and Grunstein 2007; Shi and Whetstine 2007).

Histone variants, remodelers, DNA methylation, and histone modifications regulate genes in many ways. Certain histone variants, such as H3.3, are found in transcriptionally active regions, whereas other $\mathrm{H} 3$ variants are found in silent chromatin (for review, see Kamakaka and Biggins 2005; Hake and Allis 2006; Loyola and Almouzni 2007). Chromatin remodelers can either activate or repress transcription by sliding, positioning, or exchanging nucleosomes (for review, see Cairns 2005; Kwon and Wagner 2007). Gene transcription is a tightly regulated process that involves many histone modifications (for review, see Workman 2006; Berger 2007; Kouzarides 2007; Li et al. 2007). In general, the promoter and the $5^{\prime}$ end of the coding region of active genes are enriched for acetylation of histone $\mathrm{H} 3$ or $\mathrm{H} 4$ and trimethylation of lysine 4 of histone 3 (H3K4me3). During transcription elongation, the histone variant $\mathrm{H} 3.3$ is incorporated and $\mathrm{H} 3 \mathrm{~K} 36 \mathrm{me} 3$ is deposited. Inactive gene promoters generally contain DNA methyla- tion, hypoacetylation of $\mathrm{H} 3$ and $\mathrm{H} 4, \mathrm{H} 3 \mathrm{~K} 9 \mathrm{me} 3$, and/or H3K37me3 (for review, see Workman 2006; Berger 2007; Kouzarides 2007; Li et al. 2007).

Posttranslational modification of a histone tail not only influences other modifications on the same tail (in cis), but also affects the modifications on other tails (in trans) in the same or neighboring nucleosomes (for review, see Fischle et al. 2003; Fuks 2005; Margueron et al. 2005; Nightingale et al. 2006; Kouzarides 2007). This has led to the "histone code" hypothesis, which states that histone modifications, presumably in specific combinations, provide binding sites for chromatin factors that influence gene transcription (Strahl and Allis 2000; Jenuwein and Allis 2001; Turner 2002; Ruthenburg et al. 2007b).

Chromatin factors can be recruited to their targets by direct interactions with transcription factors or by association to the basal transcriptional machinery. Another targeting mechanism involves small heterochromatic RNAs (shRNAs) that are produced by transcription of centromeric repeats and form double-stranded RNAs. These are processed by the RNA interference (RNAi) machinery and the resulting small interfering RNAs (siRNAs) target chromatin factors to the centromere, leading to heterochromatin formation. Furthermore, noncoding RNAs can direct chromatin factors to specific locations on the DNA, for example, during $\mathrm{X}$ inactivation (for review, see Fischle et al. 2003; Peterson and Laniel 2004; Bernstein and Allis 2005; Wassenegger 2005; Ruthenburg et al. 2007a).

The histone code is read by proteins with specific chromatin-binding domains (for review, see de la Cruz et al. 2005; Kouzarides 2007; Ruthenburg et al. 2007a). Examples are the chromodomain and bromodomain that bind methylated lysines and acetylated lysines, respectively. These domains are found in histone acetyltransferases (HATs), histone methyltransferases (HMTs), and remodelers that in turn can modify chromatin and regulate gene transcription.

The histone code hypothesis implies that chromatin modifications are inherited through cell division to provide memory of a transcriptional state. But how are chromatin states maintained during replication and mitosis? Active chromatin has been proposed to be inherited by 
several mechanisms that still need validation. These mechanisms include the contribution of $\mathrm{H} 3$ variants to cellular memory (Hake and Allis 2006), the influence of the chromatin state on nucleosome stability (Henikoff 2008), and the reinstatement of active chromatin due to accessibility to transcription factors after replication (Groth et al. 2007). Accordingly, activating parental histone modifications, such as acetylation and methylation, have been shown to "survive" replication (Benson et al. 2006). Alternatively, transcription factors may also dictate the cell state and chromatin state after mitosis (for review, see Egli et al. 2008). Therefore, mitosis may provide a window of opportunity to change cell fate, because both chromatin and transcription factors dissociate and reassociate during mitosis.

Silent chromatin is thought to be reinstated quickly after replication (for review, see Wallace and Orr-Weaver 2005; Groth et al. 2007). DNA methyltransferase DNMT1 is recruited to the replicated DNA by the replication factor proliferating cell nuclear antigen (PCNA) and ensures the propagation of DNA methylation (for review, see Nightingale et al. 2006; Groth et al. 2007; Martin and Zhang 2007). In addition, DNMT1 recruits histone modifiers, such as histone deacetylases (HDACs) and HMTs, and in this way might help to replicate chromatin modifications (Fig. 1) (Groth et al. 2007). PCNA recruits another chromatin factor, the chromatin assembly factor 1 (CAF1) complex (Shibahara and Stillman 1999; Zhang et al. 2000). The CAF-1 complex is involved in nucleosome assembly after replication by loading newly synthesized H3-H4 dimers onto the DNA. CAF-1 interacts with heterochromatin protein 1 (HP1) (Fig. 1), which is known to be important for heterochromatin stabilization (Murzina et al. 1999), and may in this way facilitate chromatin maturation after replication (Quivy et al. 2004). In addition to HP1,

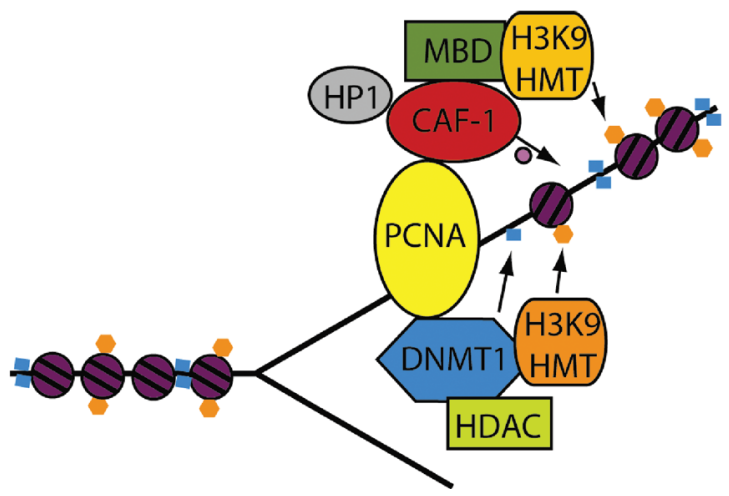

Figure 1. Inheritance of the histone code. Replication factor PCNA recruits DNA methyltransferase DNMT1 to ensure proper inheritance of DNA methylation. DNMT1 in turn is known to be associated with HDACs and an H3K9 HMT. This ensures proper inheritance of histone methylation through an epigenetic feedback loop. In addition, PCNA recruits the CAF-1 complex involved in H3-H4 loading (small, light purple sphere) to the newly replicated DNA. CAF-1 interacts with HP1 (which also can bind H3K9me3), a DNA methyl-binding domain (MBD) protein and an H3K9 HMT (which ensures propagation of histone methylation). (Blue squares) DNA methylation; (orange pentagons) histone methylation. For simplicity, only one strand is depicted.
CAF-1 binds a DNA methyl-binding domain (MBD) protein and an H3K9 HMT (Fig. 1) (Reese et al. 2003; Sarraf and Stancheva 2004). In turn, H3K9me3 is known to recruit HP1. Thus, both DNA methylation and histone methylation can immediately be reinstated after replication (for review, see Wallace and Orr-Weaver 2005; Groth et al. 2007).

\section{CHROMATIN AND THE STEM CELL STATE}

Stem cells replenish the cells present in an organism throughout its lifetime (for review, see Li and Xie 2005; Wong et al. 2005; Jones and Wagers 2008). They have two unique characteristics: the capability to self-renew and to differentiate into (several) cell types. The stem cell niche arose independently in animal and plant kingdoms and is defined by kingdom-specific transcription factors. Recently, it has become clear that chromatin factors support the unique features of mammalian stem cells (for review, see Niwa 2007a,b; Spivakov and Fisher 2007; Jaenisch and Young 2008). The role of chromatin factors in plant stem cell control is just starting to be revealed.

\section{Mammalian Stem Cell Systems}

Many stem cells are localized in stem cell niches, where a limited number of "organizer" cells maintain the stem cells by inhibiting differentiation and regulating their self-renewal. Besides the influence of the stem cell niche microenvironment, stem cells are thought to possess unique intrinsic properties. Oct4, Nanog, and Sox 2 genes are essential intrinsically for the pluripotency and self-renewal of mammalian embryonic stem (ES) cells. Oct4 encodes a POU domain transcription factor, Nanog encodes a divergent homeodomain protein, and Sox 2 encodes a high mobility group (HMG)-box transcription factor. Analysis of the targets of Oct4, Nanog, and Sox 2 revealed that they regulate themselves, one another, and key signaling pathways in stem cells and, on the other hand, repress key differentiation genes. These data suggest that complex regulatory mechanisms are at work in ES cells, probably providing stability within the system by positive and negative feedback loops (Boyer et al. 2005; Johnson et al. 2006; Loh et al. 2006; Niwa 2007a).

What makes stem cells unique? Not all progenitor cells are able to revert to a stem cell state, indicating that stem cells have unique features thought to be imposed by chromatin (for review, see Mikkers and Frisen 2005; Buszczak and Spradling 2006; Meshorer and Misteli 2006; Niwa 2007a; Spivakov and Fisher 2007). Accordingly, pluripotent ES cells contain hyperdynamic or "breathing" chromatin that is lost during differentiation. Furthermore, elevated levels of unbound histones in ES cells enhance differentiation, whereas ES cells expressing a strongly bound form of H1 show differentiation arrest. This suggests that "loose" chromatin not only is a unique trait of pluripotent cells, but also facilitates the structural chromatin changes occurring during the early stages of differentiation (Meshorer et al. 2006). That ES cells contain open chromatin is supported by the fact that ES cells are transcriptionally globally hyperactive, which is probably facil- 
itated by chromatin-remodeling factors (Efroni et al. 2008). Major changes in chromatin organization occur during early mouse embryogenesis. Heterochromatin is diffuse during the two-cell stage and is progressively assembled into condensed heterochromatin until the blastocyst stage. Condensation of chromatin is abolished by deletion of the p150 subunit of the CAF-1 complex and eventually leads to developmental arrest (Houlard et al. 2006). Thus, the CAF1 complex and extensive chromatin reorganization are essential during the early steps of mouse embryogenesis and in ES cells (Houlard et al. 2006). Possibly, the CAF-1 complex is involved in the establishment of hyperdynamic or "breathing" chromatin in ES cells.

BMI1, a member of the Polycomb repressive complex 1 (PRC1), is essential for the self-renewal of hematopoietic, neural, and cancer stem cells (for review, see ValkLingbeek et al. 2004). BMI1 negatively regulates the Ink4a/Arf locus, encoding two cell cycle inhibitors, $p 16^{\text {ink4a }}$ and $p 19^{a r f}$ (Valk-Lingbeek et al. 2004; Bruggeman et al. 2005; Molofsky et al. 2005), and thereby stimulates stem cell proliferation and prevents apoptosis (Fig. 2). Recently, it was shown that the PRC1 complex (containing BMI1) and the PRC2 complex bind to the $p 16^{\text {ink4a }}$ locus in a retinoblastoma $(\mathrm{pRb})$ family-dependent manner in differentiated fibroblasts (Fig. 2) (Bracken et al. 2007; Kotake et al. 2007). In turn, $\mathrm{pRb}$ family proteins are regulated by $\mathrm{p} 16^{\mathrm{ink} 4 \mathrm{a}}$, forming a regulatory loop (for review, see Lowe and Sherr 2003; Sharpless 2005). Possibly, elevated levels of BMI1 in stem cells ensure continuous proliferation by abolishing this feedback loop. BMI1 is mainly involved in the maintenance of adult stem cells, whereas other complexes are probably acting in ES cells (Valk-Lingbeek et al. 2004).

Recently, many genes involved in differentiation were

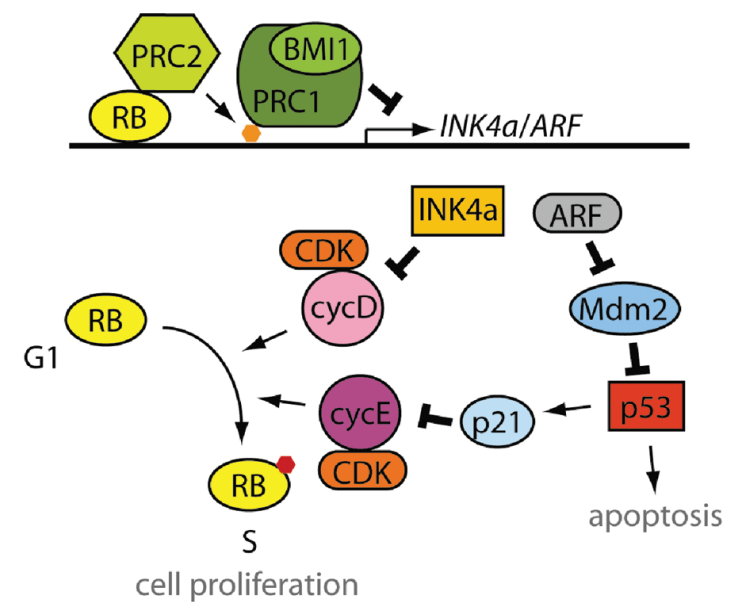

Figure 2. Cell cycle regulation by Polycomb proteins and $\mathrm{Rb}$. At the INK4a/ARF locus, $\mathrm{Rb}$ probably recruits the PRC2 complex, which mediates H3K27me3 (orange pentagon). This in turn recruits the PRC1 complex containing BMI1 and represses transcription of the Ink $4 a / A r f$ locus. ARF inhibits degradation of p53 and thereby activates apoptosis and blocks cell cycle progression through $\mathrm{p} 21$ and cycE/CDK. INK4a inhibits cycD/CDK activity. The cycD/CDK complex promotes phosphorylation of $\mathrm{Rb}$ (red pentagon), which releases $\mathrm{Rb}$ binding and thereby promotes the transition through the $\mathrm{G}_{1}-\mathrm{S}$ phase of the cell cycle. shown to posses a special chromatin signature in mouse and human ES cells. They contain both active (H3K4me2/3 and $\mathrm{H} 3 \mathrm{~K} 9$ acetylation) and repressive (H3K27me3) modifications (for review, see Buszczak and Spradling 2006; Meshorer and Misteli 2006; Gan et al. 2007). These "bivalent" domains are found exclusively in ES cells and are lost upon differentiation by resolving into either active (H3K4me3) or repressive (H3K27me3) chromatin. The $\mathrm{PRC} 2$ complex is responsible for $\mathrm{H} 3 \mathrm{~K} 27 \mathrm{me} 3$ and repression in those domains (Azuara et al. 2006; Boyer et al. 2006; Lee et al. 2006; Mikkelsen et al. 2007; Pasini et al. 2007). Interestingly, stem cell factors Oct4, Nanog, and Sox 2 are found specifically at a large subset of these differentiation genes. Therefore, stem cell pluripotency might be imposed by the intrinsic stem cell factors Oct4, Nanog, and Sox 2 through activation of a stem cell self-renewal program and a balance between activation and (a temporary) repression ("poised state") of differentiation factors by Polycomb complexes (Boyer et al. 2005; Lee et al. 2006). Differentiation into a specific lineage could be accomplished by selective activation of a subset of genes by lineage-specific transcription factors, whereas other lineages of primed differentiation genes are permanently silenced. Although the theory of the poised state is appealing, the significance of bivalent domains must be further studied (for discussion, see Gan et al. 2007; Niwa 2007a). Another point of interest is that PRC2 members are required to prevent stem cell differentiation and do not seem to affect proliferation, in contrast to PRC1 member BMI1 (Azuara et al. 2006; Boyer et al. 2006; Niwa 2007a; Pasini et al. 2007). Recently, it was proposed that bivalent domains facilitate postponement of cell-fate decisions (Pietersen and van Lohuizen 2008).

Overexpression of Oct4, Sox2, Nanog, c-Myc, and Klf4 is sufficient to convert mouse and human somatic cells into induced pluripotent stem (iPS) cells, which show characteristics of stem cells, including chromatin features such as bivalent domains and proper genomic imprinting (Takahashi and Yamanaka 2006; Niwa 2007a; Okita et al. 2007; Takahashi et al. 2007; Wernig et al. 2007; Jaenisch and Young 2008). Oncogenes c-Myc and Klf4 are not essential, but they increase the frequency of iPS cells by unknown mechanisms (for review, see Jaenisch and Young 2008). c-Myc (important for proliferation and stem cells) is required for the maintenance of active chromatin in progenitor cells through regulation of histone acetyltransferase GCN5 (Knoepfler et al. 2006) and may in this way aid in the reprogramming process (Jaenisch and Young 2008). The induction of iPS cells is enhanced by inhibitors of both DNA methyltransferase and histone deacetylases (Huangfu et al. 2008). Recently, it was shown that the pluripotent transcription factor Oct4 regulates the expression of histone demethylases Jmjd1a and Jmjd2c, which may have a role in maintaining open chromatin in stem cells. In turn, Jmjd1a mediates the access of Oct4 to the promoter of the self-renewal regulator Tcl1 (Loh et al. 2007; Niwa 2007b). Together, these data suggest that chromatin factors are important for the execution rather than the initiation of pluripotency.

In conclusion, a unique chromatin state is present in mammalian stem cells that appears to be imposed by tran- 
scription factors that program pluripotency through regulation of chromatin factors. Several classes of chromatin factors are important, including histone acetyltransferase GCN5, the CAF-1 complex, and histone demethylases. Polycomb proteins facilitate the unique characteristics of stem cells: They control the expression of genes mediating proliferation and differentiation into specific cell types.

\section{Plant Stem Cell Systems}

Similar to animals, plant stem cells are regulated by extrinsic signals from their niche (for review, see Stahl and Simon 2005; Vernoux and Benfey 2005; Williams and Fletcher 2005; Singh and Bhalla 2006; Scheres 2007). Therefore, equivalent mechanisms may be present to control stem cells, although multicellularity arose independently in both kingdoms. Postembryonically, Arabidopsis stem cells are located and maintained at two sites: the shoot apical meristem (SAM) and the root meristem (RM).

SAM stem cells produce all above-ground tissues. These stem cells are maintained at the population level and are controlled through two parallel pathways. The initiation and maintenance of the SAM and the suppression of differentiation are regulated by the homeodomain transcription factor SHOOT MERISTEMLESS (STM). In addition, stem cell maintenance is regulated by homeodomain transcription factor WUSCHEL (WUS) and the CLAVATA (CLV) receptor kinase pathway. WUS is expressed in the organizing center and induces the expression of the CLV3 ligand in the overlying stem cells. CLV3 binds the CLV1-CLV2 receptor kinase complex, which represses the expression of WUS. This negative feedback loop regulates the size of the stem cell pool (for review, see Stahl and Simon 2005; Williams and Fletcher 2005; Tucker and Laux 2007).

The RM contains stem cells that produce all underground tissues. These stem cells surround and are physically linked to the organizing center or quiescent center (QC), which is required for their maintenance (van den Berg et al. 1995). The position of the root stem cell niche is controlled through two parallel plant-specific pathways. The stem cell niche is positioned in the apical-basal direction through the accumulation of the phytohormone auxin, which is achieved by the polar localization of PIN proteins (putative auxin efflux carriers) in the plasma membrane (Blilou et al. 2005). This auxin maximum regulates the expression of AP2 domain transcription factors PLETHORA1 (PLT1) and PLT2, which are redundantly required for stem cell maintenance (Aida et al. 2004). In turn, the PLT proteins regulate the expression of PIN genes, revealing a feedback loop (Blilou et al. 2005). The stem cell niche is controlled in the radial direction through the GRAS family transcription factors SHORTROOT (SHR) and SCARECROW (SCR). SHR is expressed in the vascular tissue and moves into the outer layer (endodermis and QC), where it induces SCR expression. SCR is required cell-autonomously in the QC to maintain the surrounding stem cells (Helariutta et al. 2000; Nakajima et al. 2001; Sabatini et al. 2003; Heidstra et al. 2004). SCR appears to inhibit RETINOBLASTOMA RELATED1
(RBR1) activity in the QC or in the stem cells (Wildwater et al. 2005). RBR1 promotes the transition of stem cells to differentiating daughter cells without changes in cell cycle progression.

The position of the stem cell niche is defined by the overlap between the highest PLT and SCR expression (Aida et al. 2004). The combination of key transcription factor pathways to program stem cells resembles the combined action of pluripotent transcription factor Oct4, Nanog, and Sox 2 in animal stem cells (Johnson et al. 2006; Niwa 2007a). Similarly, the PLT stem cell transcription factors are sufficient to induce ectopic root development including a functional root stem cell niche (Aida et al. 2004; Galinha et al. 2007). It is interesting to note that, for ectopic reprogramming, PLT genes require sites of active cell division.

There are two pools of root stem cells present that produce daughter cells by asymmetric divisions and have different characteristics. The daughters derived from the distal stem cells do not divide and differentiate immediately. The proximal stem cell daughters form a transitamplifying cell population in which a few extra rounds of cell division take place. These cells contribute to the growth of the root by expansion and eventually differentiate into several cell types.

Chromatin factors are implicated in stem cell maintenance in plants. The SNF2 chromatin-remodeling factor SPLAYED (SYD) maintains the SAM during the reproductive stage through the WUS pathway. SYD directly interacts with the WUS promoter, regulates WUS transcription, and thereby promotes stem cell maintenance in the shoot (Kwon et al. 2005). This is similar to the role of remodeling factors in stem cell maintenance in the Drosophila ovary (Xi and Xie 2005) and in mammalian neural stem/progenitor cells (Lessard et al. 2007).

The PRC2 complex represses key differentiation genes in mammalian stem cells as discussed above (for review, see Buszczak and Spradling 2006; Meshorer and Misteli 2006; Gan et al. 2007). Similarly, members of Arabidopsis PRC2 complexes are required for root stem cell niche maintenance (N. Kornet and B. Scheres, unpubl.). Preliminary data indicate that RBR1 and PRC2 complexes may together control proliferation of transit-amplifying cells (our unpublished data).

Histone acetyltransferase GCN5 has been indirectly linked to expression regulation of transcription factor WUS in the floral meristem and embryo (Bertrand et al. 2003; Long et al. 2006). It is unknown whether shoot stem cells are affected directly. In addition, mutation of GCN5 causes defects in root development (Vlachonasios et al. 2003). Our data show that GCN5 is required for root stem cell maintenance through regulation of PLT expression (N. Kornet and B. Scheres, unpubl.). Furthermore, GCN5 and its cofactor ADA2b influence proliferation of transitamplifying cells (N. Kornet and B. Scheres, unpubl.).

Another chromatin factor implicated in both SAM and RM maintenance is the Arabidopsis CAF-1 complex. The mammalian CAF-1 complex subunits p150 and p60 are encoded by Arabidopsis FAS1 and FAS2 genes that are involved in nucleosome assembly and stable maintenance of epigenetic states (Kaya et al. 2001; Costa and Shaw 
2006; Schonrock et al. 2006; Ramirez-Parra and Gutierrez 2007a,b). The SAM in fas mutants is broader and flatter, the organization is disrupted, and WUS expression is expanded. In the RM, the organization of the stem cell niche is perturbed in fas mutants (Kaya et al. 2001). CAF-1 activity appears to be linked to the role of the RETINOBLASTOMA RELATED1 (RBR1) protein in cell state progression. The CAF-1 complex and RBR1 synergistically repress stem cell proliferation in the root through regulation of stem cell transcription factors $(\mathrm{N}$. Kornet and B. Scheres, unpubl.). The Arabidopsis CAF-1 complex is thought to be involved in the stable expression of key developmental genes through correct chromatin formation. The Arabidopsis CAF-1 complex was shown to influence chromatin conformation at the homeobox gene GLABRA2 (GL2). GL2 is an atrichoblast cell-fate determinant that is expressed in nonhair root cells (atrichoblasts) and is repressed in hair root cells (trichoblasts). The chromatin conformation specifically at the GL2 locus is "open" in atrichoblasts and "closed" in trichoblasts. In fas mutants, the chromatin conformation at the GL2 locus is open, regardless of the cell type, and GL2 is ectopically expressed (Costa and Shaw 2006). Furthermore, in fas mutants, the heterochromatin fraction is reduced (Kirik et al. 2006; Schonrock et al. 2006), suggesting that the CAF1 complex is involved in heterochromatin compaction. Similarly, the largest subunit of CAF-1 (p150) was found to be essential for the assembly of the heterochromatin organization in mouse embryonic stem cells, and epigenetic marks at pericentric heterochromatin are affected (Houlard et al. 2006). However, histone modifications (DNA methylation, H3K9me2, H3, and $\mathrm{H} 4$ acetylation) are not affected globally in fas mutants (Schonrock et al. 2006; Ramirez-Parra and Gutierrez 2007a). Only a small fraction of heterochromatic genes are up-regulated in fas mutants and these were mainly expressed during late $\mathrm{S}$ phase (Schonrock et al. 2006). In addition, these genes (but not their neighboring genes) contained less $\mathrm{H} 3 \mathrm{~K} 9 \mathrm{me} 2$ and more $\mathrm{H} 3$ and $\mathrm{H} 4$ acetylation (RamirezParra and Gutierrez 2007a). This suggests that the CAF-1 complex ensures the proper epigenetic inheritance of specific genes in Arabidopsis, whereas in animals, the CAF1 complex has a more general role in heterochromatin formation. It is noteworthy that the replication-associated function of the CAF-1 protein appears to be a plausible link between cell state transitions and cell cycle progression.

\section{TOWARD ANALYSIS OF STATE TRANSITIONS IN PLANT STEM CELLS}

Key transcription factors and several classes of chromatin modifying factors serve as stem cell factors in both animal and plant kingdoms. GCN5, the CAF-1 complex, and Polycomb proteins have been shown to be important in mammalian stem cells and the same is true for Arabidopsis root stem cells (our unpublished data).

In mammals, pluripotent stem cell transcription factors probably regulate chromatin factors to obtain a special chromatin state in ES cells. In Arabidopsis, stem cell transcription factors are also sufficient to induce root or shoot stem cells, and it is tempting to speculate that they likewise regulate chromatin factors to stabilize cellular states. Conversely, stem-cell-associated chromatin factors (remodeler SYD and HAT GCN5) regulate key stem cell transcription factors (WUS and PLT) (Kwon et al. 2005; N. Kornet and B. Scheres, unpubl.). Feedback from these chromatin modifiers to transcription factors may serve to stabilize cellular states characterized by a defined transcriptional program. It remains to be seen whether feedback circuits between chromatin factors and transcription factors have been invented twice during evolution of multicellular plants and animals. Alternatively, chromatin factors might have been already at the nexus of proliferative and differentiation cell states of a common unicellular ancestor.

In the Arabidopsis root meristem, the dosage of the PLT stem cell regulators controls the transition from stem cell to transit-amplifying cells and the transition from transit-amplifying cell to terminal differentiation (Galinha et al. 2007). Part of the ability to shift expression and cell states can be explained by a feedback loop between PLT activity and the distribution of its upstream regulator, the plant hormone auxin, which establishes a PLT protein gradient. However, efficient blocking of state transitions (for example, from stem cell to transit-amplifying cell) requires high PLT levels and a simultaneous reduction of RBR1 levels (Galinha et al. 2007). Given the well-known connections between RBR1 and chromatin modification complexes in both kingkoms (Frolov and Dyson 2004; Hennig et al. 2005; Giacinti and Giordano 2006), it seems likely that the rapid shift between these states is facilitated by the interplay among transcription factors that instruct stem cell or transit-amplifying cell fates and chromatin modifiers. Our current data support a formal model for the requirement of chromatin modifiers and core transcription factors in this process (Fig. 3). It is possible to follow differentiation of root stem cell descen-

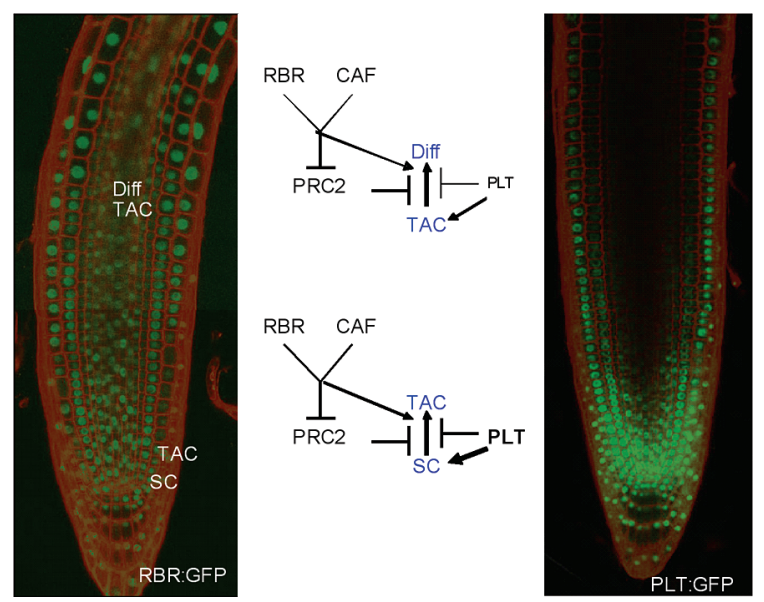

Figure 3. Interaction model between chromatin factors and core stem cell factors in root. Two state transitions are depicted: from stem cell (SC) to transit-amplifying cell (TAC) and from transitamplifying cell to terminally differentiating cell (Diff). Arrows and repression bars depict a possible scenario by which RBR1, CAF-1 complex subunits, and PRC2 complex subunits may control state transitions. 
dants in continuous cell files and it is now feasible to determine their gene expression state at selective stages of differentiation (Brady et al. 2007). This should allow us to dissect state transitions during the differentiation trajectory of pluripotent plant stem cells and to understand the hitherto unresolved role of chromatin factors and cell cycle regulators in this process.

\section{REFERENCES}

Aida, M., Beis, D., Heidstra, R., Willemsen, V., Blilou, I., Galinha, C., Nussaume, L., Noh, Y.S., Amasino, R., and Scheres, B. 2004. The PLETHORA genes mediate patterning of the Arabidopsis root stem cell niche. Cell 119: 109-120.

Azuara, V., Perry, P., Sauer, S., Spivakov, M., Jorgensen, H.F., John, R.M., Gouti, M., Casanova, M., Warnes, G., Merkenschlager, M., and Fisher, A.G. 2006. Chromatin signatures of pluripotent cell lines. Nat. Cell Biol. 8: 532-538.

Bannister, A.J. and Kouzarides, T. 2005. Reversing histone methylation. Nature 436: 1103-1106.

Benson, L.J., Gu, Y., Yakovleva, T., Tong, K., Barrows, C., Strack, C.L., Cook, R.G., Mizzen, C.A., and Annunziato, A.T. 2006. Modifications of $\mathrm{H} 3$ and $\mathrm{H} 4$ during chromatin replication, nucleosome assembly, and histone exchange. J. Biol. Chem. 281: 9287-9296.

Berger, S.L. 2007. The complex language of chromatin regulation during transcription. Nature 447: 407-412.

Bernstein, B.E., Meissner, A., and Lander, E.S. 2007. The mammalian epigenome. Cell 128: 669-681.

Bernstein, E. and Allis, C.D. 2005. RNA meets chromatin. Genes Dev. 19: 1635-1655.

Bertrand, C., Bergounioux, C., Domenichini, S., Delarue, M., and Zhou, D.X. 2003. Arabidopsis histone acetyltransferase AtGCN5 regulates the floral meristem activity through the WUSCHEL/AGAMOUS pathway. J. Biol. Chem. 278: $28246-$ 28251.

Blilou, I., Xu, J., Wildwater, M., Willemsen, V., Paponov, I., Friml, J., Heidstra, R., Aida, M., Palme, K., and Scheres, B. 2005. The PIN auxin efflux facilitator network controls growth and patterning in Arabidopsis roots. Nature 433: 39-44.

Boyer, L.A., Lee, T.I., Cole, M.F., Johnstone, S.E., Levine, S.S., Zucker, J.P., Guenther, M.G., Kumar, R.M., Murray, H.L., Jenner, R.G., et al. 2005. Core transcriptional regulatory circuitry in human embryonic stem cells. Cell 122: 947-956.

Boyer, L.A., Plath, K., Zeitlinger, J., Brambrink, T., Medeiros, L.A., Lee, T.I., Levine, S.S., Wernig, M., Tajonar, A., Ray, M.K., et al. 2006. Polycomb complexes repress developmental regulators in murine embryonic stem cells. Nature 441: 349-353.

Bracken, A.P., Kleine-Kohlbrecher, D., Dietrich, N., Pasini, D., Gargiulo, G., Beekman, C., Theilgaard-Mönch, K., Minucci, S., Porse, B.T., Marine, J.C., et al. 2007. The Polycomb group proteins bind throughout the INK4A-ARF locus and are disassociated in senescent cells. Genes Dev. 21: 525-530.

Brady, S.M., Orlando, D.A., Lee, J.Y., Wang, J.Y., Koch, J., Dinneny, J.R., Mace, D., Ohler, U., and Benfey, P.N. 2007. A high-resolution root spatiotemporal map reveals dominant expression patterns. Science 318: 801-806.

Bruggeman, S.W., Valk-Lingbeek, M.E., van der Stoop, P.P., Jacobs, J.J., Kieboom, K., Tanger, E., Hulsman, D., Leung, C., Arsenijevic, Y., Marino, S., and van Lohuizen, M. 2005. Ink $4 a$ and Arf differentially affect cell proliferation and neural stem cell self-renewal in Bmil-deficient mice. Genes Dev. 19: $1438-1443$.

Buszczak, M. and Spradling, A.C. 2006. Searching chromatin for stem cell identity. Cell 125: 233-236.

Cairns, B.R. 2005. Chromatin remodeling complexes: Strength in diversity, precision through specialization. Curr. Opin. Genet. Dev. 15: 185-190.

Costa, S. and Shaw, P. 2006. Chromatin organization and cell fate switch respond to positional information in Arabidopsis.
Nature 439: 493-496.

de la Cruz, X., Lois, S., Sanchez-Molina, S., and MartinezBalbas, M.A. 2005. Do protein motifs read the histone code? Bioessays 27: 164-175.

Efroni, S., Duttagupta, R., Cheng, J., Dehghani, H., Hoeppner, D.J., Dash, C., Bazett-Jones, D.P., Le Grice, S., McKay, R.D., Buetow, K.H., et al. 2008. Global transcription in pluripotent embryonic stem cells. Cell Stem Cell 2: 437-447.

Egli, D., Birkhoff, G., and Eggan, K. 2008. Mediators of reprogramming: Transcription factors and transitions through mitosis. Nat. Rev. Mol. Cell Biol. 9: 505-516.

Fischle, W., Wang, Y., and Allis, C.D. 2003. Histone and chromatin cross-talk. Curr. Opin. Cell Biol. 15: 172-183.

Frolov, M.V. and Dyson, N.J. 2004. Molecular mechanisms of E2F-dependent activation and pRB-mediated repression. $J$. Cell Sci. 117: 2173-2181.

Fuks F. 2005. DNA methylation and histone modifications: Teaming up to silence genes. Curr. Opin. Genet. Dev. 15: 490-495.

Galinha, C., Hofhuis, H., Luijten, M., Willemsen, V., Blilou, I., Heidstra, R., and Scheres, B. 2007. PLETHORA proteins as dose-dependent master regulators of Arabidopsis root development. Nature 449: 1053-1057.

Gan, Q., Yoshida, T., McDonald, O.G., and Owens, G.K. 2007. Concise review: Epigenetic mechanisms contribute to pluripotency and cell lineage determination of embryonic stem cells. Stem Cells 25: 2-9.

Giacinti, C. and Giordano, A. 2006. RB and cell cycle progression. Oncogene 25: 5220-5227.

Groth, A., Rocha, W., Verreault, A., and Almouzni, G. 2007. Chromatin challenges during DNA replication and repair. Cell 128: 721-733.

Hake, S.B. and Allis, C.D. 2006. Histone H3 variants and their potential role in indexing mammalian genomes: The "H3 barcode hypothesis." Proc. Natl. Acad. Sci. 103: 6428-6435.

Heidstra, R., Welch, D., and Scheres, B. 2004. Mosaic analyses using marked activation and deletion clones dissect Arabidopsis SCARECROW action in asymmetric cell division. Genes Dev. 18: 1964-1969.

Helariutta, Y., Fukaki, H., Wysocka-Diller, J., Nakajima, K., Jung, J., Sena, G., Hauser, M.T., and Benfey, P.N. 2000. The SHORT-ROOT gene controls radial patterning of the Arabidopsis root through radial signaling. Cell 101: 555-567.

Henikoff, S. 2008. Nucleosome destabilization in the epigenetic regulation of gene expression. Nat. Rev. Genet. 9: 15-26.

Hennig, L., Bouveret, R., and Gruissem, W. 2005. MSI1-like proteins: An escort service for chromatin assembly and remodeling complexes. Trends Cell Biol. 15: 295-302.

Houlard, M., Berlivet, S., Probst, A.V., Quivy, J.P., Hery, P., Almouzni, G., and Gerard, M. 2006. CAF-1 is essential for heterochromatin organization in pluripotent embryonic cells. PLoS Genet. 2: e181.

Huangfu, D., Maehr, R., Guo, W., Eijkelenboom, A., Snitow, M., Chen, A.E., and Melton, D.A. 2008. Induction of pluripotent stem cells by defined factors is greatly improved by small-molecule compounds. Nat. Biotechnol. 26: 795-797.

Jaenisch, R. and Young, R. 2008. Stem cells, the molecular circuitry of pluripotency and nuclear reprogramming. Cell 132: 567-582.

Jenuwein, T. and Allis, C.D. 2001. Translating the histone code. Science 293: 1074-1080.

Johnson, B.V., Rathjen, J., and Rathjen, P.D. 2006. Transcriptional control of pluripotency: Decisions in early development. Curr. Opin. Genet. Dev. 16: 447-454.

Jones, D.L. and Wagers, A.J. 2008. No place like home: Anatomy and function of the stem cell niche. Nat. Rev. Mol. Cell Biol. 9: 11-21.

Kamakaka, R.T. and Biggins, S. 2005. Histone variants: Deviants? Genes Dev. 19: 295-310.

Kaya, H., Shibahara, K.I., Taoka, K.I., Iwabuchi, M., Stillman, B., and Araki, T. 2001. FASCIATA genes for chromatin assembly factor-1 in Arabidopsis maintain the cellular organization of apical meristems. Cell 104: 131-142.

Kirik, A., Pecinka, A., Wendeler, E., and Reiss, B. 2006. The 
chromatin assembly factor subunit FASCIATA1 is involved in homologous recombination in plants. Plant Cell 18: 2431-2442.

Knoepfler, P.S., Zhang, X.Y., Cheng, P.F., Gafken, P.R., McMahon, S.B., and Eisenman, R.N. 2006. Myc influences global chromatin structure. EMBO J. 25: 2723-2734.

Kotake, Y., Cao, R., Viatour, P., Sage, J., Zhang, Y., and Xiong, Y. 2007. pRB family proteins are required for $\mathrm{H} 3 \mathrm{~K} 27$ trimethylation and Polycomb repression complexes binding to and silencing p $16^{I N{ }^{I N}}$ - tumor suppressor gene. Genes Dev. 21: 49-54.

Kouzarides, T. 2007. Chromatin modifications and their function. Cell 128: 693-705.

Kwon, C.S. and Wagner, D. 2007. Unwinding chromatin for development and growth: A few genes at a time. Trends Genet. 23: 403-412.

Kwon, C.S., Chen, C., and Wagner, D. 2005. WUSCHEL is a primary target for transcriptional regulation by SPLAYED in dynamic control of stem cell fate in Arabidopsis. Genes Dev. 19: 992-1003.

Lee, T.I., Jenner, R.G., Boyer, L.A., Guenther, M.G., Levine, S.S., Kumar, R.M., Chevalier, B., Johnstone, S.E., Cole, M.F., Isono, K., et al. 2006. Control of developmental regulators by Polycomb in human embryonic stem cells. Cell 125: 301-313.

Lessard, J., Wu, J.I., Ranish, J.A., Wan, M., Winslow, M.M., Staahl, B.T., Wu, H., Aebersold, R., Graef, I.A., and Crabtree, G.R. 2007. An essential switch in subunit composition of a chromatin remodeling complex during neural development. Neuron 55: 201-215.

Li, B., Carey, M., and Workman, J.L. 2007. The role of chromatin during transcription. Cell 128: 707-719.

Li, L. and Xie, T. 2005. Stem cell niche: Structure and function. Annu. Rev. Cell Dev. Biol. 21: 605-631.

Loh, Y.H., Zhang, W., Chen, X., George, J., and Ng, H.H. 2007. Jmjd1a and Jmjd2c histone H3 Lys 9 demethylases regulate self-renewal in embryonic stem cells. Genes Dev. 21: 2545 2557.

Loh, Y.H., Wu, Q., Chew, J.L., Vega, V.B., Zhang, W., Chen, X., Bourque, G., George, J., Leong, B., Liu, J., et al. 2006. The Oct4 and Nanog transcription network regulates pluripotency in mouse embryonic stem cells. Nat. Genet. 38: 431-440.

Long, J.A., Ohno, C., Smith, Z.R., and Meyerowitz, E.M. 2006. TOPLESS regulates apical embryonic fate in Arabidopsis. Science 312: 1520-1523.

Lowe, S.W. and Sherr, C.J. 2003. Tumor suppression by Ink4aArf: Progress and puzzles. Curr. Opin. Genet. Dev. 13: 77-83.

Loyola, A. and Almouzni, G. 2007. Marking histone H3 variants: How, when and why? Trends Biochem. Sci. 32: 425-433.

Luger, K. and Hansen, J.C. 2005. Nucleosome and chromatin fiber dynamics. Curr. Opin. Struct. Biol. 15: 188-196.

Margueron, R., Trojer, P., and Reinberg, D. 2005. The key to development: Interpreting the histone code? Curr. Opin. Genet. Dev. 15: 163-176.

Martin, C. and Zhang, Y. 2007. Mechanisms of epigenetic inheritance. Curr. Opin. Cell Biol. 19: 266-272.

Mellor, J. 2005. The dynamics of chromatin remodeling at promoters. Mol. Cell 19: 147-157.

Meshorer, E. and Misteli, T. 2006. Chromatin in pluripotent embryonic stem cells and differentiation. Nat. Rev. Mol. Cell Biol. 7: 540-546.

Meshorer, E., Yellajoshula, D., George, E., Scambler, P.J., Brown, D.T., and Misteli, T. 2006. Hyperdynamic plasticity of chromatin proteins in pluripotent embryonic stem cells. Dev. Cell 10: 105-116.

Mikkelsen, T.S., Ku, M., Jaffe, D.B., Issac, B., Lieberman, E., Giannoukos, G., Alvarez, P., Brockman, W., Kim, T.K., Koche, R.P., et al. 2007. Genome-wide maps of chromatin state in pluripotent and lineage-committed cells. Nature 448: $553-560$.

Mikkers, H. and Frisen, J. 2005. Deconstructing stemness. EMBO J. 24: 2715-2719.

Molofsky, A.V., He, S., Bydon, M., Morrison, S.J., and Pardal, R. 2005. Bmi-1 promotes neural stem cell self-renewal and neural development but not mouse growth and survival by repressing the $\mathrm{p} 16^{\text {Ink4a }}$ and $\mathrm{p} 19^{\text {Arf }}$ senescence pathways. Genes Dev. 19: 1432-1437.

Murzina, N., Verreault, A., Laue, E., and Stillman, B. 1999. Heterochromatin dynamics in mouse cells: Interaction between chromatin assembly factor 1 and HP1 proteins. Mol. Cell 4: 529540.

Nakajima, K., Sena, G., Nawy, T., and Benfey, P.N. 2001. Intercellular movement of the putative transcription factor SHR in root patterning. Nature 413: 307-311.

Nightingale, K.P., O’Neill, L.P., and Turner, B.M. 2006. Histone modifications: Signalling receptors and potential elements of a heritable epigenetic code. Curr. Opin. Genet. Dev. 16: $125-136$.

Niwa, H. 2007a. How is pluripotency determined and maintained? Development 134: 635-646.

Niwa, H. 2007b. Open conformation chromatin and pluripotency. Genes Dev. 21: 2671-2676.

Okita, K., Ichisaka, T., and Yamanaka, S. 2007. Generation of germline-competent induced pluripotent stem cells. Nature 448: 313-317.

Pasini, D., Bracken, A.P., Hansen, J.B., Capillo, M., and Helin, K. 2007. The polycomb group protein Suz12 is required for embryonic stem cell differentiation. Mol. Cell. Biol. 27: 3769-3779.

Peterson, C.L. and Laniel, M.A. 2004. Histones and histone modifications. Curr. Biol. 14: R546-R551.

Pietersen, A.M. and van Lohuizen, M. 2008. Stem cell regulation by polycomb repressors: Postponing commitment. Curr. Opin. Cell Biol. 20: 201-207.

Quivy, J.P., Roche, D., Kirschner, D., Tagami, H., Nakatani, Y., and Almouzni, G. 2004. A CAF-1 dependent pool of HP1 during heterochromatin duplication. EMBO J. 23: 3516-3526.

Ramirez-Parra, E. and Gutierrez, C. 2007a. E2F regulates FASCIATA1, a chromatin assembly gene whose loss switches on the endocycle and activates gene expression by changing the epigenetic status. Plant Physiol. 144: 105-120.

Ramirez-Parra, E. and Gutierrez, C. 2007b. The many faces of chromatin assembly factor 1 . Trends Plant Sci. 12: 570-576.

Reese, B.E., Bachman, K.E., Baylin, S.B., and Rountree, M.R. 2003. The methyl-CpG binding protein MBD1 interacts with the p150 subunit of chromatin assembly factor 1 . Mol. Cell. Biol. 23: 3226-3236.

Ruthenburg, A.J., Allis, C.D., and Wysocka, J. 2007a. Methylation of lysine 4 on histone H3: Intricacy of writing and reading a single epigenetic mark. Mol. Cell 25: 15-30.

Ruthenburg, A.J., Li, H., Patel, D.J., and Allis, C.D. 2007 b. Multivalent engagement of chromatin modifications by linked binding modules. Nat. Rev. Mol. Cell Biol. 8: 983-994.

Sabatini, S., Heidstra, R., Wildwater, M., and Scheres, B. 2003. SCARECROW is involved in positioning the stem cell niche in the Arabidopsis root meristem. Genes Dev. 17: 354-358.

Sarraf, S.A. and Stancheva, I. 2004. Methyl-CpG binding protein MBD1 couples histone $\mathrm{H} 3$ methylation at lysine 9 by SETDB1 to DNA replication and chromatin assembly. Mol. Cell 15: 595-605.

Scheres, B. 2007. Stem-cell niches: Nursery rhymes across kingdoms. Nat. Rev. Mol. Cell Biol. 8: 345-354.

Schonrock, N., Exner, V., Probst, A., Gruissem, W., and Hennig, L. 2006. Functional genomic analysis of CAF-1 mutants in Arabidopsis thaliana. J. Biol. Chem. 281: 9560-9568.

Shahbazian, M.D. and Grunstein, M. 2007. Functions of sitespecific histone acetylation and deacetylation. Annu. Rev. Biochem. 76: 75-100.

Sharpless, N.E. 2005. INK4a/ARF: A multifunctional tumor suppressor locus. Mutat. Res. 576: 22-38.

Shi, Y. and Whetstine, J.R. 2007. Dynamic regulation of histone lysine methylation by demethylases. Mol. Cell 25: 1-14.

Shibahara, K. and Stillman, B. 1999. Replication-dependent marking of DNA by PCNA facilitates CAF-1-coupled inheritance of chromatin. Cell 96: 575-585.

Singh, M.B. and Bhalla, P.L. 2006. Plant stem cells carve their own niche. Trends Plant Sci. 11: 241-246.

Spivakov, M. and Fisher, A.G. 2007. Epigenetic signatures of 
stem-cell identity. Nat. Rev. Genet. 8: 263-271.

Stahl, Y. and Simon, R. 2005. Plant stem cell niches. Int. J. Dev. Biol. 49: 479-489.

Strahl, B.D. and Allis, C.D. 2000. The language of covalent histone modifications. Nature 403: 41-45.

Takahashi, K. and Yamanaka, S. 2006. Induction of pluripotent stem cells from mouse embryonic and adult fibroblast cultures by defined factors. Cell 126: 663-676.

Takahashi, K., Tanabe, K., Ohnuki, M., Narita, M., Ichisaka, T., Tomoda, K., and Yamanaka, S. 2007. Induction of pluripotent stem cells from adult human fibroblasts by defined factors. Cell 131: 861-872.

Tucker, M.R. and Laux, T. 2007. Connecting the paths in plant stem cell regulation. Trends Cell Biol. 17: 403-410.

Turner, B.M. 2002. Cellular memory and the histone code. Cell 111: 285-291.

Valk-Lingbeek, M.E., Bruggeman, S.W., and van Lohuizen, M. 2004. Stem cells and cancer: The Polycomb connection. Cell 118: $409-418$.

van den Berg, C., Willemsen, V., Hage, W., Weisbeek, P., and Scheres, B. 1995. Cell fate in the Arabidopsis root meristem determined by directional signalling. Nature 378: 62-65.

Vernoux, T. and Benfey, P.N. 2005. Signals that regulate stem cell activity during plant development. Curr. Opin. Genet. Dev. 15: 388-394.

Vlachonasios, K.E., Thomashow, M.F., and Triezenberg, S.J. 2003. Disruption mutations of $A D A 2 b$ and GCN5 transcriptional adaptor genes dramatically affect Arabidopsis growth, development, and gene expression. Plant Cell 15: 626638.

Wallace, J.A. and Orr-Weaver, T.L. 2005. Replication of heterochromatin: Insights into mechanisms of epigenetic inheritance. Chromosoma 114: 389-402.

Wassenegger, M. 2005. The role of the RNAi machinery in heterochromatin formation. Cell 122: 13-16.

Wernig, M., Meissner, A., Foreman, R., Brambrink, T., Ku, M., Hochedlinger, K., Bernstein, B.E., and Jaenisch, R. 2007. In vitro reprogramming of fibroblasts into a pluripotent ES-celllike state. Nature 448: 318-324.

Wildwater, M., Campilho, A., Perez-Perez, J.M., Heidstra, R., Blilou, I., Korthout, H., Chatterjee, J., Mariconti, L., Gruissem, W., and Scheres, B. 2005. The RETINOBLASTOMA-RELATED gene regulates stem cell maintenance in Arabidopsis roots. Cell 123: 1337-1349.

Williams, L. and Fletcher, J.C. 2005. Stem cell regulation in the Arabidopsis shoot apical meristem. Curr. Opin. Plant Biol. 8: 582-586.

Wong, M.D., Jin, Z., and Xie, T. 2005. Molecular mechanisms of germline stem cell regulation. Annu. Rev. Genet. 39: 173-195.

Workman, J.L. 2006. Nucleosome displacement in transcription. Genes Dev. 20: 2009-2017.

$\mathrm{Xi}, \mathrm{R}$. and Xie, T. 2005. Stem cell self-renewal controlled by chromatin remodeling factors. Science 310: 1487-1489.

Zhang, Z., Shibahara, K., and Stillman, B. 2000. PCNA connects DNA replication to epigenetic inheritance in yeast. Nature 408: $221-225$. 


\title{
$8_{\mathrm{CSH}}^{\infty} \mathrm{C}$ Cold Spring Harbor Symposia SYMPOSIA on Quantitative Biology
}

\section{Stem Cell Factors in Plants: Chromatin Connections}

\author{
N. Kornet and B. Scheres
}

Cold Spring Harb Symp Quant Biol 2008 73: 235-242 originally published online January 15, 2009 Access the most recent version at doi:10.1101/sqb.2008.73.043

References This article cites 108 articles, 30 of which can be accessed free at: http://symposium.cshlp.org/content/73/235.full.html\#ref-list-1

License

Email Alerting Receive free email alerts when new articles cite this article - sign up in the box at the Service top right corner of the article or click here. 